dr hab.inz. Marian Medwid,prof. IPS

prof.dr hab.inz. Agnieszka Merkisz-Guranowska

Politechnika Poznańska

mgr inz. Jan Strzemkowski

mgr inż. Jarosław Królikowski

Instytut Pojazdów Szynowych "TABOR"

\title{
Bimodal transport system with horizontal, transverse transhipment of semi-trailers
}

\section{System transportu bimodalnego z poziomym, poprzecznym przeładunkiem naczep}

\begin{abstract}
The article presents the conception of an innovative bimodal rolling stock system adapted for the transverse horizontal loading of semi-trailers on the railway bogies equipped with appropriate adapters. The logistic diagram of the organization of the transhipment terminal is presented. The conception of the solution of adapters construction (central and final) and adaptation of the existing bimodal semi- trailer for transverse loading is illustrated. The possibilities of automation of service activities during transhipment of semi-trailers are also indicated

$W$ artykule zaprezentowano koncepcje innowacyjnego systemu taboru bimodalnego przystosowanego do poprzecznego, poziomego załadunku naczep na wózki kolejowe wyposażone w odpowiednie adaptery. Przedstawiono schemat logistyczny organizacji terminala przeładunkowego. Zilustrowano koncepcję rozwiqzania konstrukcji adapterów (środkowego i końcowego) oraz adaptacji istniejacej naczepy bimodalnej do poprzecznego załadunku. Wskazano również możliwości automatyzacji czynności obstugowych przy przeładunku naczep.
\end{abstract}

\section{Introduction}

In the nineties of the last century the research works on developing a number of bimodal rolling stock solutions were undertaken in many European countries. The prototypes known as Road-Railer Europe (American solution adopted to the European conditions), Kombi rail, Trans railer, Coda E. In Poland the technical documentation of the TABOR 1 system, adapted to the high speed in freight traffic Vmax $=160 \mathrm{~km} / \mathrm{h}$, was also developed in this period. A train prototype was built and the thorough tests were carried out at the CNTK, at present IKOL Warsaw and at the German research center FTZ Minden.

In 2011, the technical documentation of the TABOR 2 bimodal rolling stock was started on standard Y25 bogies with a block brake, prepared for operation at $100 \mathrm{~km} / \mathrm{h}$, at axle load on the track of $225 \mathrm{KN}$ and 120 $\mathrm{km} / \mathrm{h}$ at the wheelset axle load of the $200 \mathrm{KN}$. New adapters were made for the construction of the prototype and Y25 bogies equipped with a complete brake system and semi-trailers built for the prototype up to a speed of $160 \mathrm{~km} / \mathrm{h}$ were used. A prototype composed of two box semi-trailers and a cistern is shown in Figure 1.

\section{Wstęp}

W latach 90-tych ubiegłego stulecia w wielu krajach europejskich podjęto prace badawcze nad opracowaniem szeregu rozwiązań taboru bimodalnego. Powstały prototypy znane pod nazwą Road-Railer Europa (rozwiązanie amerykańskie adoptowanie do warunków europejskich), Kombi rail, Trans railer, Coda E. W Polsce również opracowano w tym okresie dokumentację techniczną systemu TABOR 1, przystosowanego do dużych prędkości $\mathrm{w}$ ruchu towarowym $\mathrm{V}_{\max }=160$ $\mathrm{km} / \mathrm{h}$. Zbudowano prototyp pociagu oraz przeprowadzono gruntowne badania wykonane w CNTK, obecnie IKOL Warszawa oraz w niemieckim ośrodku badawczym FTZ Minden.

W 2011 roku przystapiono do opracowania dokumentacji technicznej taboru bimodalnego TABOR 2 na standardowych wózkach Y25 z hamulcem klockowym, przygotowanym do eksploatacji z prędkością $100 \mathrm{~km} / \mathrm{h}$, przy nacisku osi na tor $225 \mathrm{KN}$ oraz 120 $\mathrm{km} / \mathrm{h}$ przy nacisku osi zestawu kołowego $200 \mathrm{KN}$. Do budowy prototypu wykonano nowe adaptery i wykorzystano wózki Y25 wyposażone w kompletny układ hamulcowy oraz naczepy zbudowane dla prototypu do prędkości $160 \mathrm{~km} / \mathrm{h}$. Prototyp złożony z dwóch naczep skrzyniowych i cysterny przedstawiono na rysunku 1. 


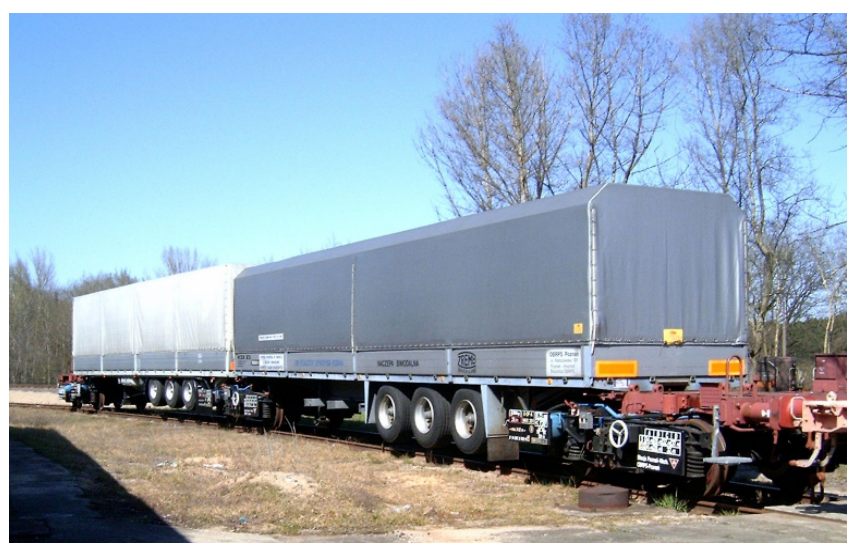

Rys. 1. Prototyp taboru bimodalnego

Fig. 1. Prototype of bimodal rolling stock

The bimodal system is not adapted to the transport of standard semi-trailers. The bimodal semi-trailer differs significantly from the standard semi-trailer and it must be designed from scratch, according to the applicable road and railway requirements. In the traditional bimodal system, the serial horizontal loading is used by connecting the semi-trailer with the end bogie and then there is the loading of the semitrailers on the middle bogies successively, closing the train set with the second end bogie. This joining process is time-consuming. It is possible to limit the connection time using a series-parallel load, e.g. on two adjacent tracks, and then connect two sets into one. Bimodal systems TABOR 1 and TABOR 2 as well as train connection technology are presented, among others, in monographs [1,2].

The subject of the article is the presentation of an innovative conception of a bimodal system, where the characteristic feature of the system is the transverse loading of bimodal semi-trailers on the adapters of railway bogies.

\section{Presentation of rolling stock conception}

Figure 2 illustrates the bimodal rolling stock adapted to the horizontal transverse transshipment. The rolling stock includes the following sets:

- bimodal bogies (reference number in Fig .1),

- end adapters (2),

- central adapters (3),

- bimodal semi- trailers (4).
System bimodalny nie jest przystosowany do transportu standardowych naczep. Bimodalna naczepa różni się znacznie od naczepy standardowej i należy ją zaprojektować od podstaw, według obowiązujących wymagań drogowych i kolejowych. W tradycyjnym systemie bimodalnym stosuje się szeregowy załadunek poziomy łącząc naczepe $\mathrm{z}$ wózkiem końcowym a następnie kolejno następuje załadunek naczep na wózki środkowe, zamykając skład pociagu drugim wózkiem końcowym. Taki proces łączenia jest czasochłonny. Można ograniczyć czas łączenia stosując załadunek szeregowo-równoległy np. na dwóch sąsiednich torach, a następnie dwa składy połączyć w jeden. Systemy bimodalne TABOR 1 i TABOR 2 oraz technologię łączenia pociagu zaprezentowano między innymi w monografiach [1,2].

Przedmiotem artykułu jest prezentacja innowacyjnej koncepcji systemu bimodalnego, gdzie cechą charakterystyczną systemu jest poprzeczny załadunek naczep bimodalnych na adaptery wózków kolejowych.

\section{Prezentacja koncepcji taboru}

$\mathrm{Na}$ rysunku 2 zilustrowano tabor bimodalny przystosowany do poprzecznego przeładunku poziomego. W skład taboru wchodzą następujące zespoły:

- wózki bimodalne (oznaczenie na rys. - 1),

- adaptery końcowe (2),

- adaptery środkowe (3),

- naczepy bimodalne (4).

\subsection{Wózki z adapterami}

W systemie tym mogą mieć zastosowanie różnego typu wózki kolejowe pod warunkiem, że ich konstrukcja pozwala na zabudowę kompletnych urządzeń hamulcowych oraz odpowiednio usytuowanych czterech ślizgów bocznych dla wózka środkowego oraz dwóch dla wózka końcowego. W przedstawionej koncepcji zaimplementowano standardowe wózki kolejowe Y25. $\mathrm{Na}$ rysunkach 3 i 3a przedstawiono wózek $\mathrm{z}$ zabudowanym adapterem środkowym, a rysunki 4 i 4a pokazują wózek z adapterem końcowym.

Adapter środkowy składa się z dwóch symetrycznych części o konstrukcji skrzynkowej połączonych ze sobą przegubem kulistym (5). Adapter dolny (6) jest oparty na wózku za pośrednictwem czopa skrętu (7) oraz
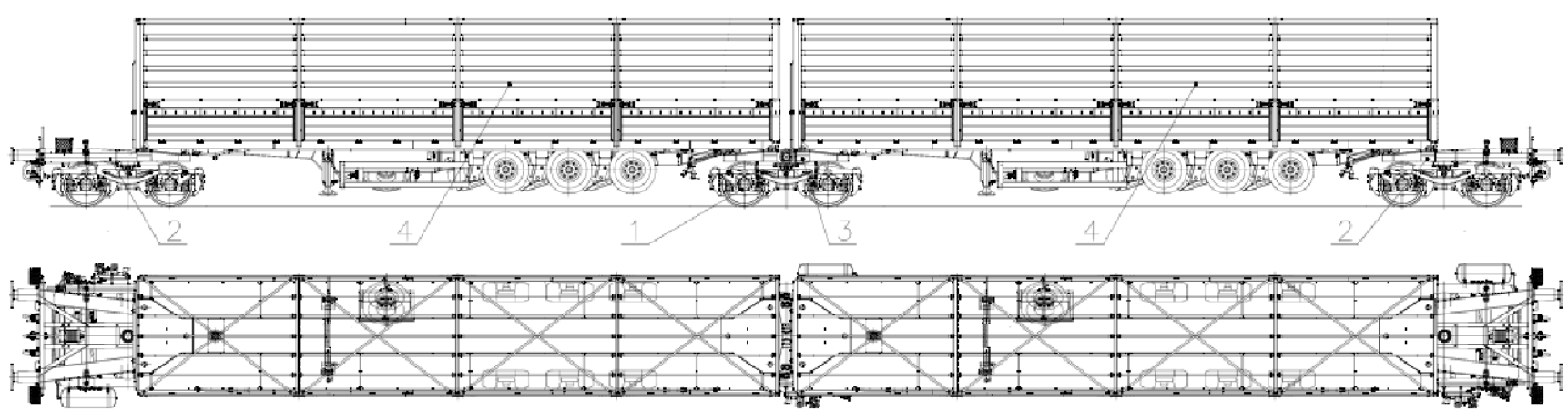

Rys. 2. Tabor bimodalny

Fig. 2. Bimodal rolling stock 


\subsection{Bogies with adapters}

In this system, various types of railway bogies may be used, provided that their construction allows for the installation of complete braking devices and four side bearers of the central bogie two for the end bogie respectively. In the presented conception, standard railway Y25 bogies are implemented. Figures 3 and 3 a show a bogie with the built-in central adapter, and figures 4 and 4 a show a bogie with the end adapter.

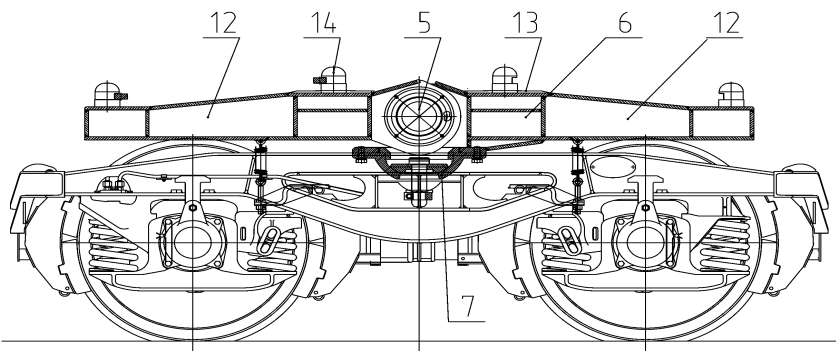

Rys. 3. Wózek z adapterem środkowym (widok wózka i przekrój adaptera)

Fig. 3. Bogie with the central adapter (view of the bogie and adapter section)

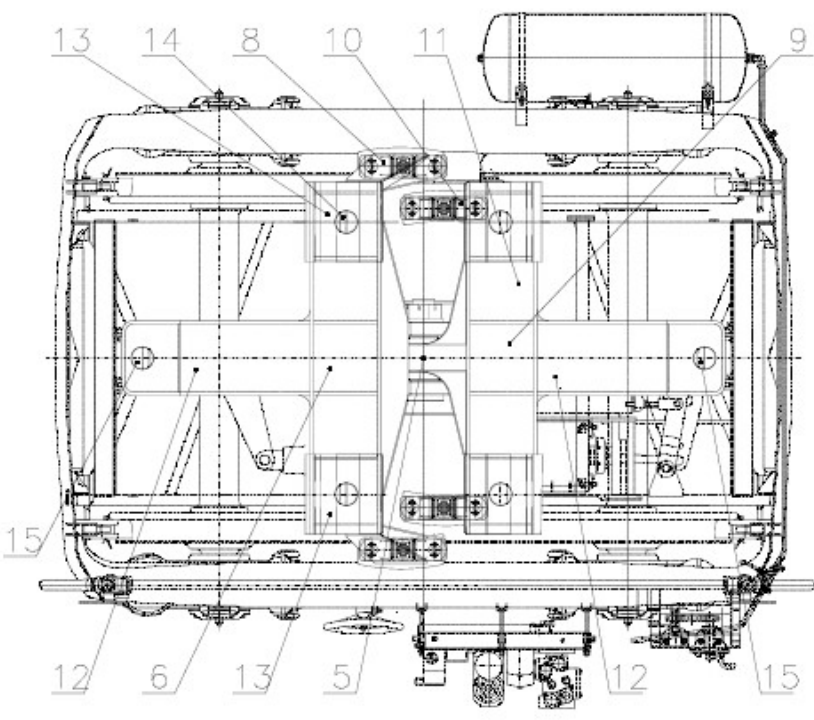

Rys. 3a. Wózek z adapterem środkowym (widok z góry)

Fig. 3a. Bogie with the central adapter (top view)

The central adapter consists of two symmetrical parts with a box construction connected together by a ball joint (5). The lower adapter (6) is supported by the bogie via a pivot (7) and two side bearers (8). The upper adapter (9) is attached into the lower adapter by means of a ball joint (5) and supported on the side bearers (10). The load-bearing structure of adapters (lower and upper) are the transverse beams (11) and longitudinal beams (12). At the ends of transverse beams there are saddle plates (13) for supporting of the semi-trailer and two coupling pins (14), and at the end of longitudinal beams one coupling pin (15) located in the longitudinal axis of the adapter.

The end adapter in the part intended for attachment of the semi-trailer is built identically to the central adapter and additionally is equipped with a frame dwóch ślizgów bocznych (8). Adapter górny (9) zamocowano $\mathrm{w}$ adapterze dolnym za pomoca przegubu kulistego (5) oraz oparto na ślizgach bocznych (10). Konstrukcją nośną adapterów (dolnego i górnego) stanowią belki poprzeczne (11) oraz belki podłużne (12). Na końcach belek poprzecznych przewidziano płyty siodłowe (13) do oparcia naczepy oraz dwa czopy sprzęgowe (14), a na końcu belek podłużnych jeden czop sprzęgowy (15) zlokalizowany w osi wzdłużnej adaptera.

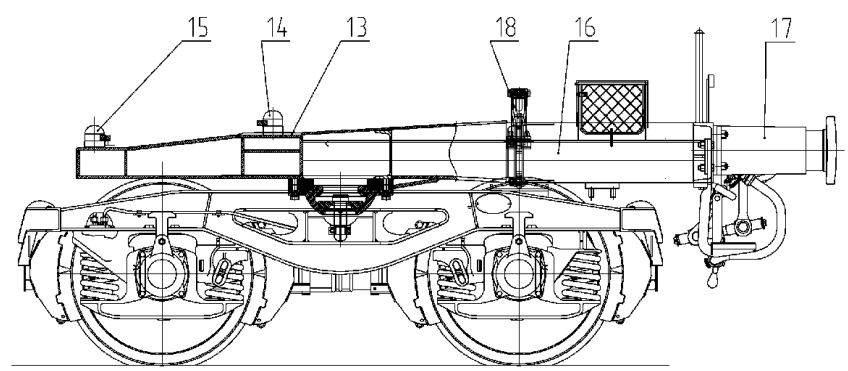

Rys. 4. Wózek z adapterem końcowym

Fig. 4. Bogie with the end adapter

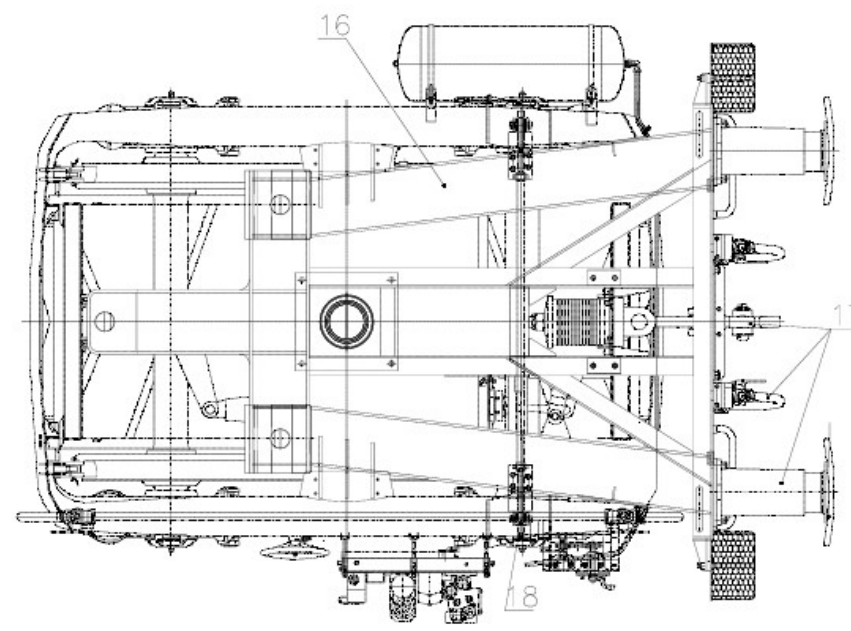

Rys. 4a. Wózek z adapterem końcowym (widok z góry)

Fig. 4a. Bogie with the end adapter (top view)

Adapter końcowy w części przeznaczonej do zamocowania naczepy zbudowano identycznie jak w adapterze środkowym i dodatkowo wyposażono w konstrukcję ramową (16), w której zabudowano urządzenia pociagowo-zderzne (17) do połączenia adaptera $z$ lokomotywą lub składem pociagu. Do utrzymania adaptera $\mathrm{w}$ pozycji poziomej $\mathrm{w}$ stanie swobodnym zastosowano odpowiednie podpory (18) unoszone po załadunku naczepy na adapter.

\subsection{Naczepa bimodalna}

Naczepa bimodalna do poziomego, poprzecznego przeładunku (rys.5) jest pod względem konstrukcji i wyposażenia podobna do naczepy systemu TABOR 1 i TABOR 2 za wyjątkiem urządzeń sprzęgowych łączących adaptery z naczepa. Czopy sprzęgowe przeniesiono $\mathrm{z}$ naczepy na adaptery a urządzenia ryglujące $\mathrm{z}$ adapterów na naczepę. 


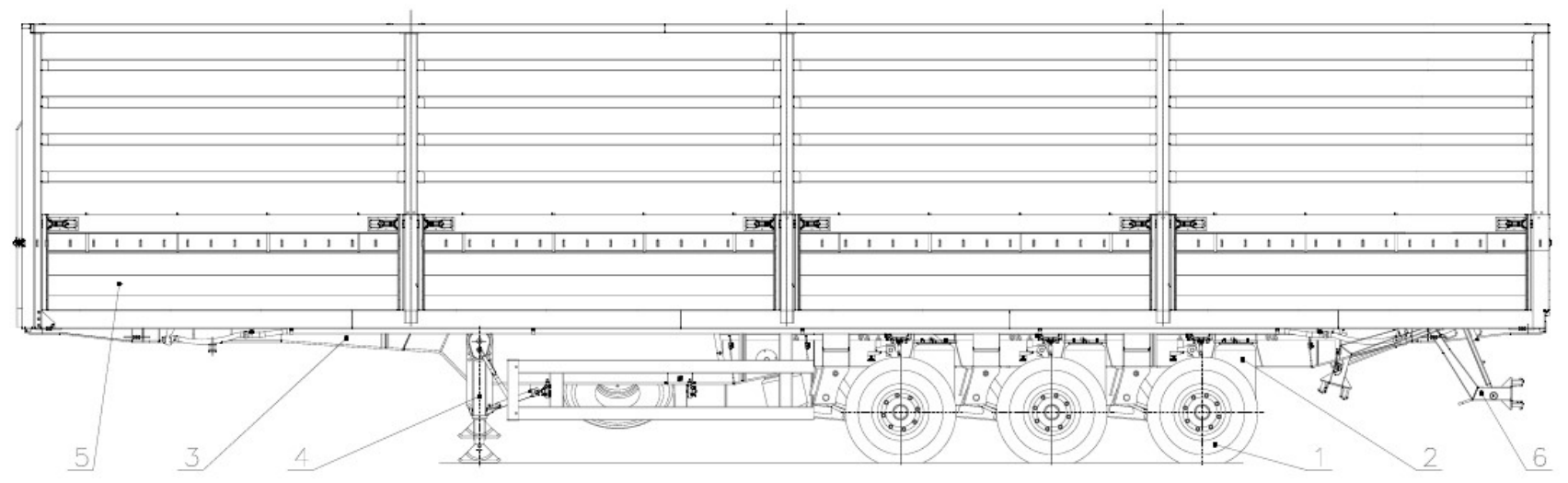

Rys. 5. Naczepa bimodalna do poziomego, poprzecznego przeładunku

Fig. 5. Bimodal semi-trailer for horizontal, transverse transhipment

structure (16), in which the buffing and draw gears (17) are built-in to connect the adapter with the locomotive or train set. To keep the adapter in a horizontal position in a free state, the appropriate supports (18) lifted after loading of the semi-trailer on the adapter are used.

\subsection{Bimodal semi-trailer}

A bimodal semi-trailer for horizontal transverse transhipment (Fig. 5) is similar to the semi-trailer of TABOR 1 and TABOR 2 systems in terms of construction and equipment, with the exception of coupling devices connecting the adapters with the semi-trailer. The coupling pins are moved from the semi-trailer to the adapters and the locking devices from the adapters to the semi-trailer.

The main components of the semi-trailer are marked on the drawing:

- road axles with wheels (1),

- load-bearing bellows (2),

- semi-trailer frame (3),

- supporting leg (4),

- built-in body (5),

- tilting buffer (6).

Figure 5 shows the semi-trailer in side view, while figure 6 shows the semi-trailer section. The location of the sleeves placed in the headstocks of the semitrailer frame and the locking devices are marked on the cross-section. The individual frame units are marked as follows:

- headstock (1),

- central beam (2),

- cross-beam (3),

- outside beam of the frame(4),

- ouside sleeve (5),

- inside sleeve (6),

- guide (7),

- saddle of semi-trailer (8),

- fastening bolt (9),

- connecting belt (10),

- handle (11),

- return spring (12).
$\mathrm{Na}$ rysunku zaznaczono główne zespoły składowe naczepy:

- osie drogowe z kołami (1),

- miechy nośne (2),

- rama naczepy (3),

- noga podporowa (4),

- zabudowa nadwozia (5),

- zderzak odchylny (6).

Na rysunku 5 przedstawiono naczepe $\mathrm{w}$ widoku $\mathrm{z}$ bo$\mathrm{ku}$, podczas gdy rysunek 6 pokazuje przekrój naczepy. Na przekroju zaznaczono lokalizację tulei umieszczonych w czołownicach ramy naczepy oraz urządzenia ryglujące. Poszczególne zespoły ramy oznaczono następująco:

- czołownica (1),

- belka centralna (2),

- belka poprzeczna (3),

- belka zewnętrzna ramy (4),

- tuleja zewnętrzna (5),

- tuleja wewnętrzna (6),

- prowadnica (7),

- siodło naczepy (8),

- rygiel mocujaccy (9),

- taśma łącznikowa (10),

- uchwyt (11),

- sprężyna powrotna (12).
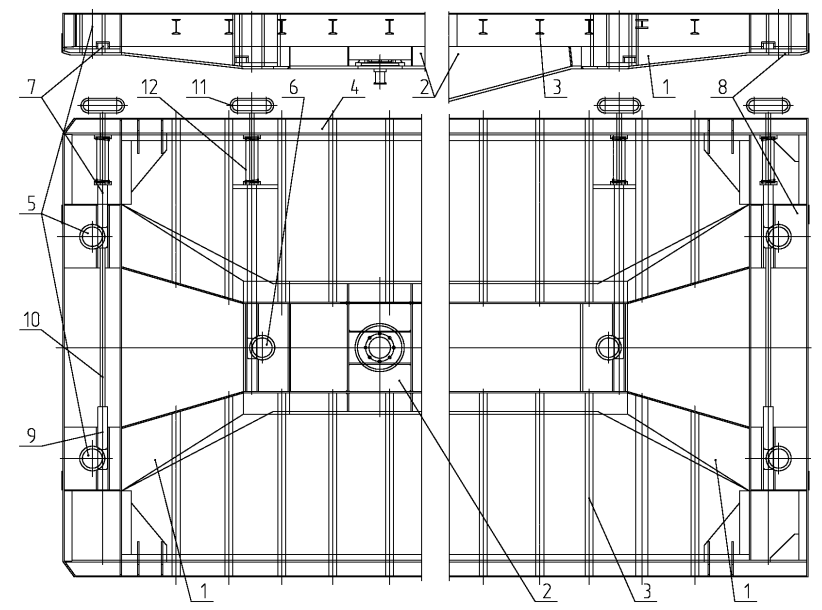

Rys. 6. Przekrój ramy naczepy

Fig. 6. Cross-section of the semi-trailer frame 


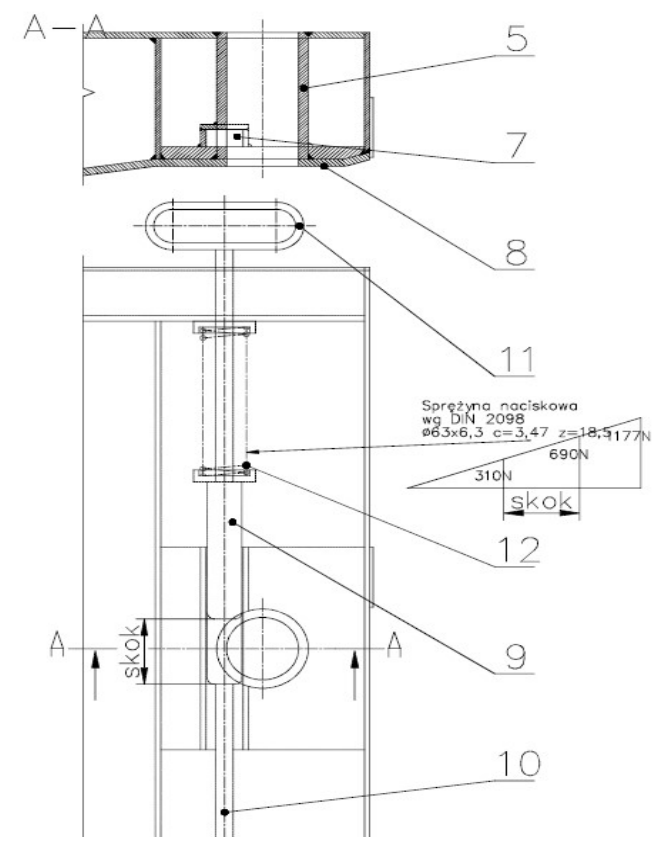

Rys. 6a. Szczegóły ramy naczepy

Fig. 6a. Details of the semi-trailer frame
Przy montażu naczepy na adapterach należy ustawić naczepe, tak aby tuleje zewnętrzne (5) i wewnętrzne (6) ramy znajdowały się nad czopami sprzęgowymi adapterów (rys. 2) z dokładnością do plus minus 40mm.

Przy opuszczaniu naczepy na adaptery należy przestrzegać zasady, aby przed oparciem siodeł naczepy na siodłach adapterów zaryglować w pierwszej kolejności rygle czopów wewnętrznych (15) (rys. 3), a następnie po oparciu naczepy na siodłach adaptera, rygle czopów zewnętrznych. Ryglowanie naczepy w adapterach następuje po zwolnieniu sprężyny powrotnej (12) (rys. 6) i wprowadzeniu rygli mocujących (9) w wycięcia wykonane w czopach sprzęgowych (14) i (15) (rys. 3a i 4).

Na rysunkach 7 i 7 a pokazano naczepe przed osadzeniem na adapterach (rys. 7) oraz po opuszczeniu ramy naczepy do oparcia na adapterach i uniesieniu kół drogowych naczepy do utraty kontaktu z podłożem (rys. 7a).

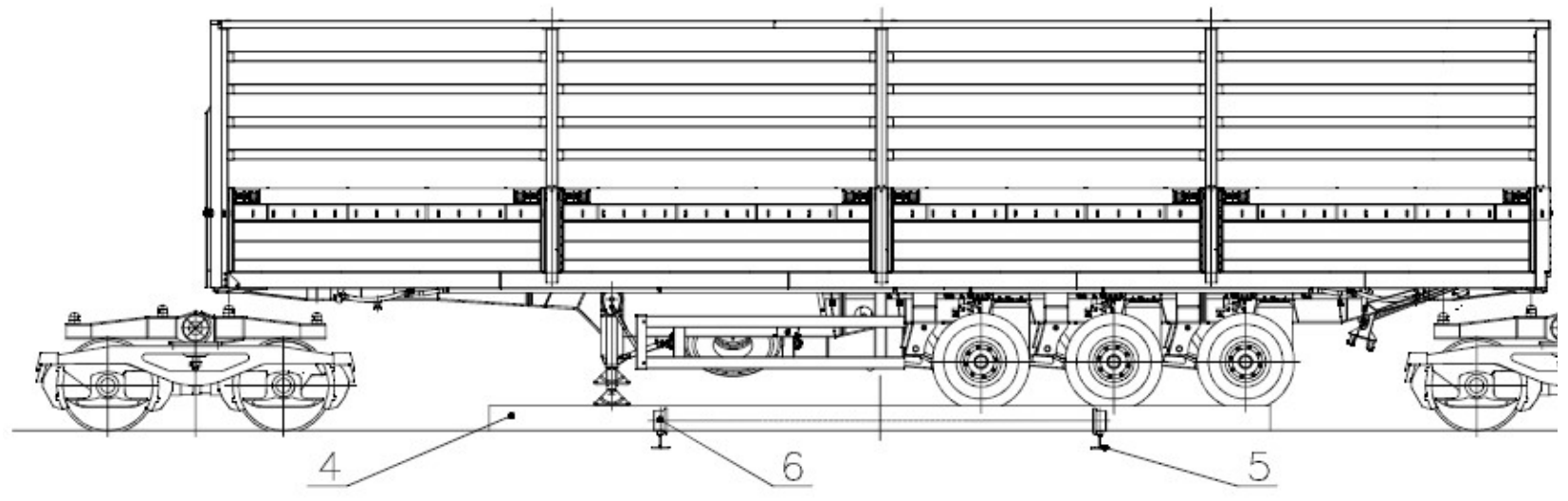

Rys. 7. Naczepa przed opuszczeniem do oparcia na adapterach

Fig. 7. Semi-trailer before lowering to the support on adapters

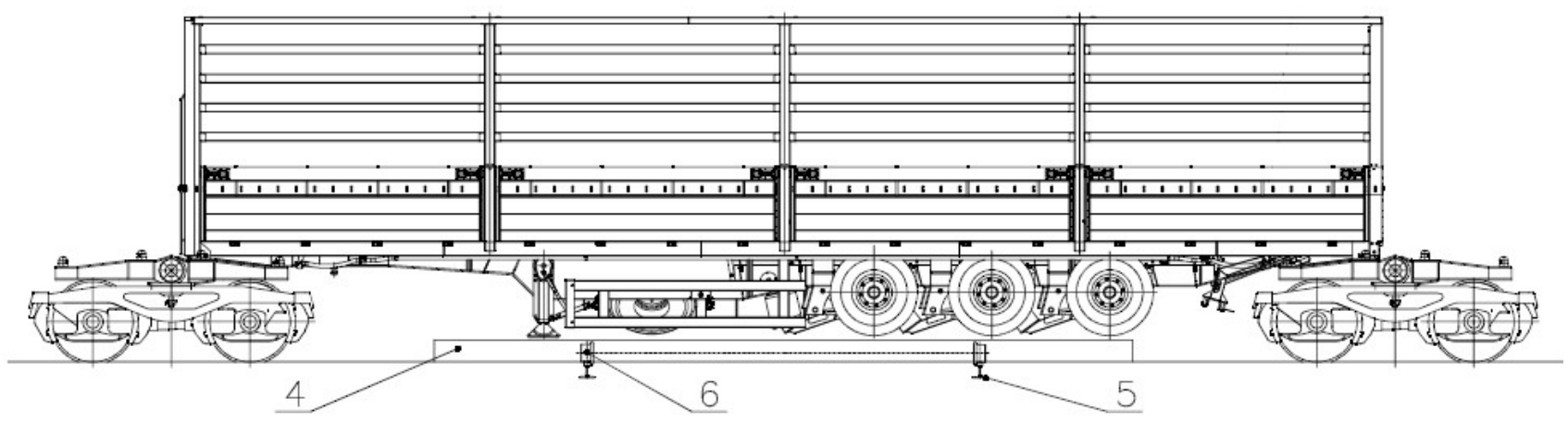

Rys. 7a. Naczepa opuszczona na adaptery - koła uniesione

Fig. 7a. Semi-trailer lowered on the adapters - raised wheels

During assembly of the semi-trailer on the adapters, the semi-trailer should be positioned so that the outside (5) and inside (6) sleeves of the frame are above the coupling pins of the adapters (Fig. 2) with an accuracy of plus or minus $40 \mathrm{~mm}$.

During lowering of the semi-trailer onto the adapters,

\section{Terminal przeladunkowy}

$\mathrm{Na}$ rysunkach 8,9 oraz 10 zaprezentowano trzy warianty organizacji terminala przeładunkowego wyposażonego w tor kolejowy (1) zagłębiony do poziomu główek szyn zrównanym z poziomem placu manewrowego. W odpowiedniej odległości od toru kolejowe- 
it is necessary to obey the rule that before supporting of the saddles of the semi-trailer on the adapter's saddles, first the bolts of the inside pins (15) should be bolted (Figure 3), and then after supporting of the semi-trailer on the adapter's saddles, the bolts of the outside pins. Locking of the semi-trailer in the adapters follows the release of the return spring (12) (Fig. 6) and the introduction of the fastening bolts (9) into the notches made in the coupling pins (14) and (15) (Figures 3a and 4). go (1) zlokalizowano stanowiska przeładunkowe (2) złożone z podjazdów (3) oraz segmentu środkowego (4), który oparto na szynach prowadzących (5) ułożonych prostopadle do toru kolejowego. Segment środkowy wyposażono w rolki prowadzace (6), które pozwalają na przemieszczanie segmentu $\mathrm{w}$ kierunku prostopadłym do toru kolejowego (rys. 7 i 7a). Przed pierwszym załadunkiem naczep należy na torze kolejowym ustawić wózki środkowe (7) oraz wózki końcowe, rozstawione na torze w ściśle określonej odległości.

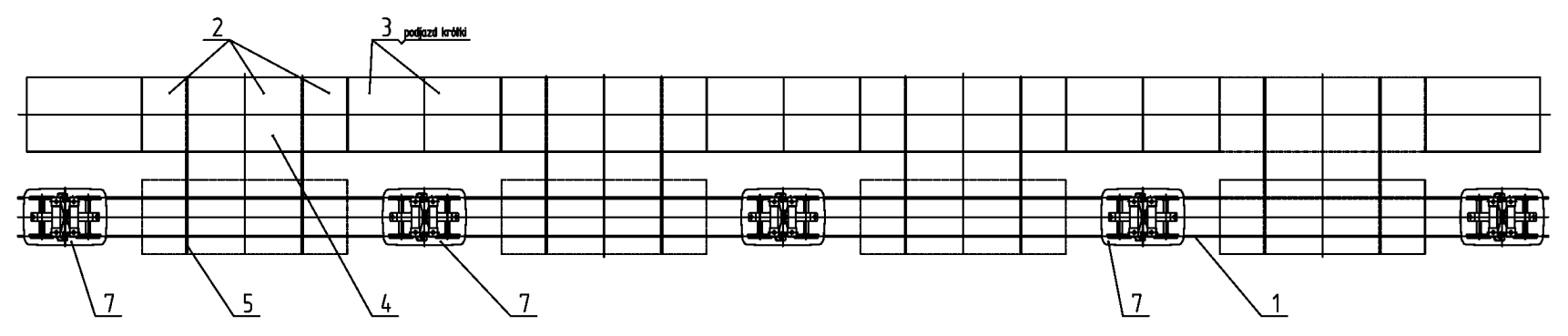

Rys. 8. Terminal przeładunkowy (wariant 1)

Fig. 8. Transhipment terminal (variant 1)

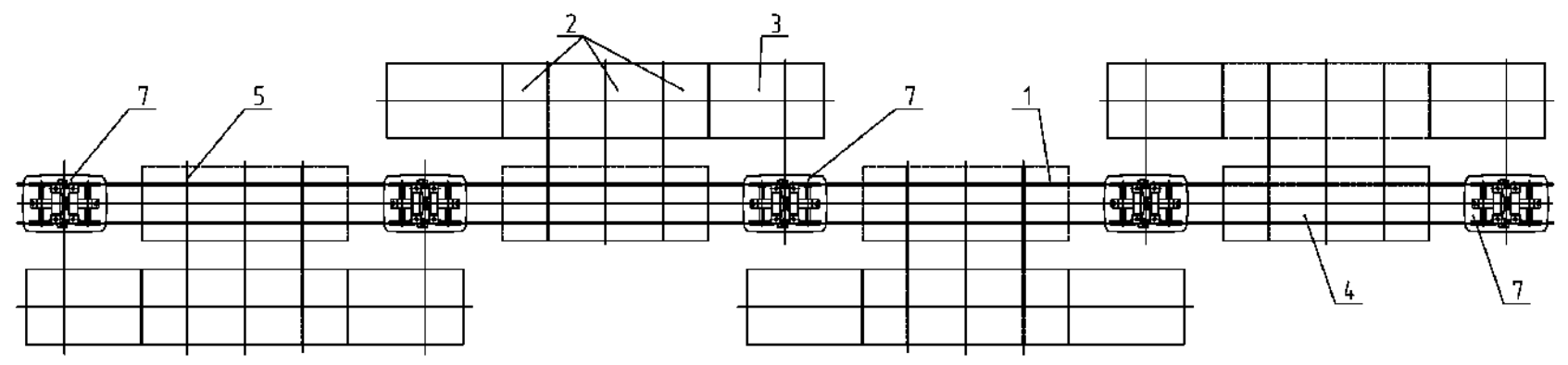

Rys. 9. Terminal przeładunkowy (wariant 2)

Fig. 9. Transhipment terminal (variant 2)

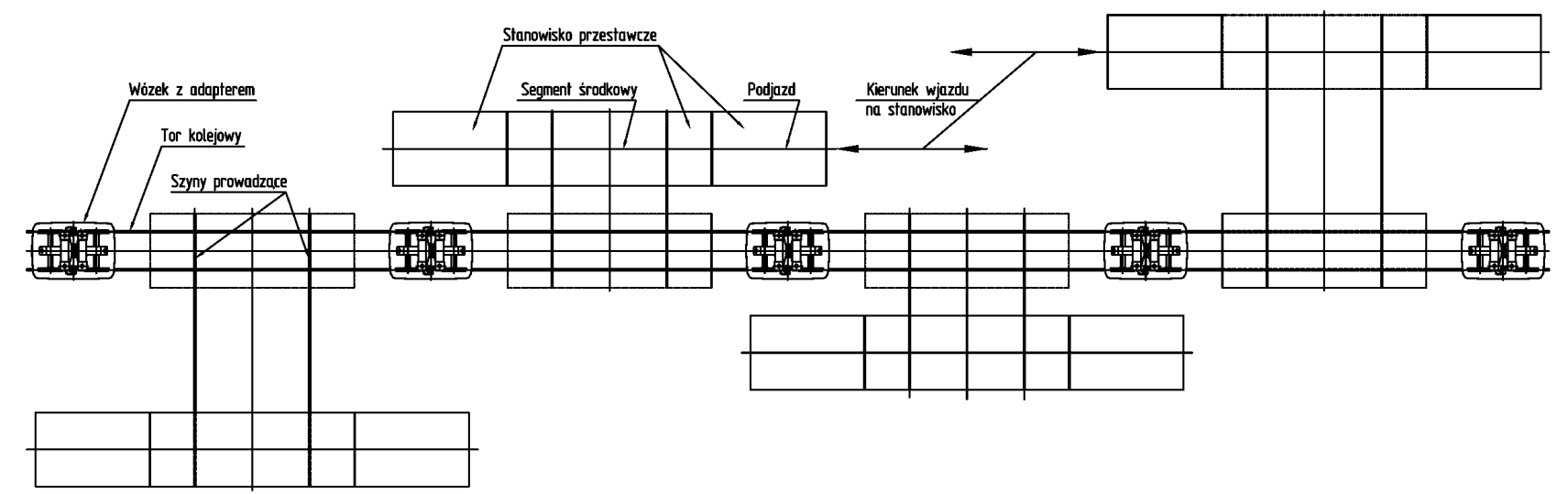

Rys. 10. Terminal przeładunkowy (wariant 3)

Fig. 10. Transhipment terminal (variant 3)

Figures 7 and 7 a show the semi-trailer before mounting on the adapters (Fig. 7) and after lowering of the frame of the semi-trailer to the support on the adapters and lifting of the semi-trailer's road wheels to the loss of contact with the ground (Fig. 7a).
Wariant 1 (rys. 8) organizacji terminala charakteryzuje się szeregowym rozstawieniem stanowisk przeładunkowych usytuowanych po jednej stronie toru kolejowego w odległościach limitowanych rozstawem wózków na torze kolejowym. Takie rozplanowanie poło- 


\section{Transhipment terminal}

Figures 8, 9 and 10 present three variants of the organization of a transhipment terminal equipped with a railway track (1) hollowed to the level of rail heads equalized with the maneuver yard level. At an appropriate distance from the railway track (1), the transhipment stands (2) are located, consisting of ramps (3) and a central segment (4), which is based on the guide rails (5) arranged perpendicularly to the railway track. The middle segment is equipped with the guide rollers (6) that allow the segment to be moved in a perpendicular direction to the railway track (Figures 7 and 7a). Before the first loading of semi-trailers, the central bogies (7) and the end bogies, which are set on the railway track at a specific distance, should be placed on the railway track. żenia stanowisk przeładunkowych ogranicza manewrowość ciąnika $\mathrm{z}$ naczepą $\mathrm{w}$ procesie wtaczania naczepy na stanowisko przeładowcze. Manewrowość ciagnika z naczepa jest łatwiejsza w przypadku ułożenia stanowisk przeładowczych naprzemiennie po obu stronach toru według schematu przedstawionego na rys. 9 (wariant 2 organizacji terminala). Na rysunku 10 pokazano wariant 3 organizacji terminala, gdzie stanowiska przeładunkowe są ulokowane naprzemiennie po obu stronach toru $\mathrm{w}$ dwóch równoległych odpowiednio przemieszczonych trasach wprowadzania naczepy na stanowiska przeładunkowe. W tym przypadku wprowadzanie naczepy na stanowiska przestawcze powinno być najłatwiejsze. Na rysunku 11 zilustrowano terminal $\mathrm{z}$ naczepą umieszczoną na stanowisku przestawczym gotową do przemieszczenia $\mathrm{w}$ oś toru kolejowego.

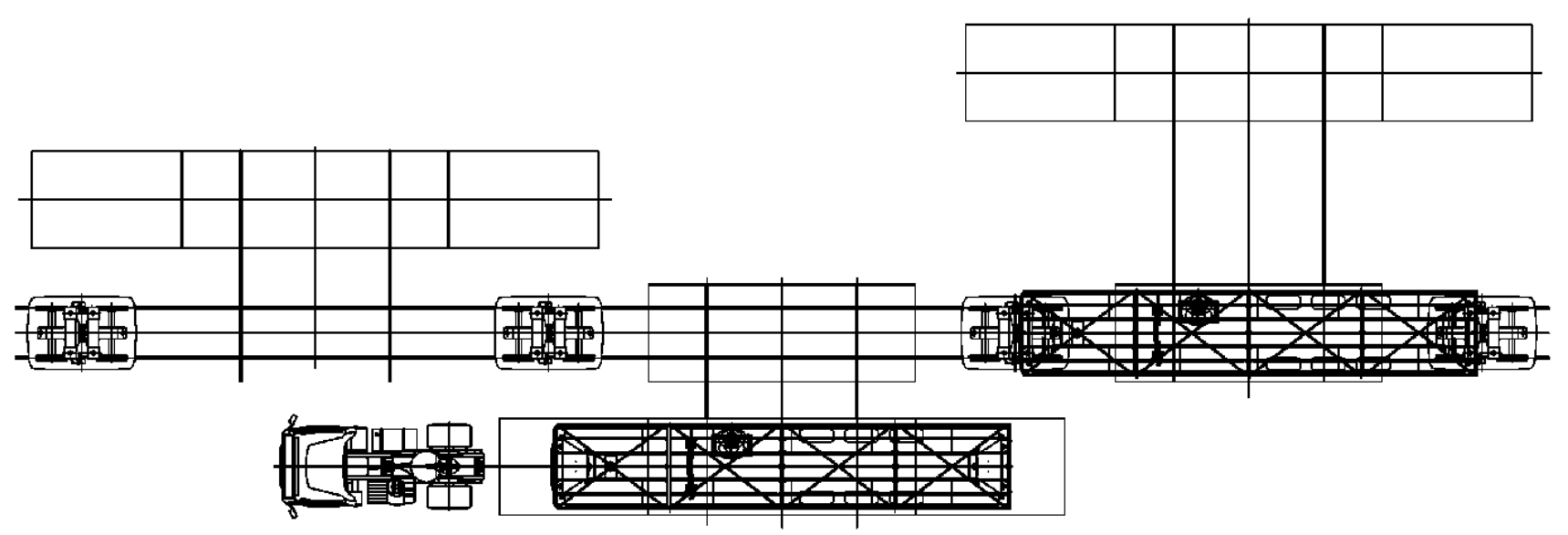

Rys. 11. Naczepy na stanowisku przestawczym Fig. 11. Semi-trailers on the change-over stand

Variant 1 (Fig. 8) of the organization of the terminal is characterized by the serial arrangement of transhipment stands located on one side of the railway track at distances limited by the wheel-base of bogies on the railway track. Such layout of the transhipment stands location limits the maneuverability of the tractor with the semi-trailer in the process of rolling the semi-trailer to the transhipment stand. Maneuverability of the tractor with the semi-trailer is easier in the case of location of the stands alternately on both sides of the track according to the scheme shown in Fig. 9 (variant 2 of the terminal organization). Figure 10 shows the variant 3 of the terminal organization, where the transhipment stands are located alternately on both sides of the track in two parallel appropriately displaced routes of placing the semi-trailer onto the transhipment stands. In this case, the introduction of the semi-trailer on the change-over stands should be the easiest. Figure 11 illustrates the terminal with the semi-trailer placed on the change-over stand ready for movement in the axis of the railway track.

\section{Załadunek naczep}

Załadunek naczep na adapterach przeprowadza się w następujących etapach:

1. Wprowadzenie naczepy na stanowisko przeładunkowe.

2. Uniesienie naczepy na maksymalną wysokość za pomocą:

-miechów nośnych ciagnika - przód naczepy,

-miechów nośnych naczepy - tył naczepy.

3. Opuszczenie nogi podporowej naczepy.

4. Wyprowadzenie ciagnika spod naczepy.

5. Przemieszczenie poprzeczne części środkowej stanowiska wraz z naczepą do pokrycia się osi wzdłużnej naczepy z osiami wózków $\mathrm{z}$ adapterami.

6. Opuszczenie nadwozia naczepy do oparcia się na ramy naczepy na adapterach:

-przód naczepy za pomocą nogi podporowej naczepy,

-tył naczepy za pomocą miechów podnoszenia osi drogowych.

7. Zaryglowanie naczepy na adapterach. 
Loading of semi-trailers on the adapters is carried out in the following stages:

1. Introduction of the semi-trailer on the loading stand.

2. Lifting of the semi-trailer to the maximum height with:

-load-bearing bellows of tractor? front of the semi-trailer,

-load-bearing bellows of semi-trailep rear of the semi-trailer.

3. Lowering of the supporting leg of the semitrailer.

4. Take the tractor out under the semi-trailer.

5. Transverse movement of the central part of the stand with the semi-trailer to coincide of the longitudinal axle of the semi-trailer with the axles of bogies with adapters.

6. Lowering of the semi-trailer's body to support of the semi-trailer's frame on the adapters:

-front of the semi-trailer using the supporting leg of the semi-trailer,

-rear of the semi-trailer using the lifting bellows of the road axles.

7. Locking of the semi-trailers on the adapters.

8. Lifting of the road axles of the semi-trailer.

9. Locking of the road axles.

10.Returning of the central section of the transhipmrent stand to the starting position.

The pneumatic suspension of the semi-trailer should be equipped with the load-bearing bellows with the appropriate stroke and the lifting bellows of the axle, so that the road wheels will rise to the required height after the semi-trailer is mounted on the adapters.

The following parameters should be taken into account when selecting the value of the bellows stroke:

- distance of the saddles of semi-trailer from the saddles of adapters before the semi-trailer is mounted on the adapters $-150 \mathrm{~mm}$,

- deflection of the suspension of the bogies after the semi-trailer is mounted on the adapters $40 \mathrm{~mm}$,
8. Uniesienie osi drogowych naczepy.

9. Zaryglowanie osi drogowych.

10. Wycofanie środkowego segmentu stanowiska przeładunkowego do pozycji wyjściowej.

Zawieszenie pneumatyczne naczepy należy wyposażyć w miechy nośne o odpowiednim skoku oraz miechy podnoszenia osi, aby tak koła drogowe podniosły się na wymaganą wysokość po osadzeniu naczepy na adapterach.

Dobierając wartości skoku miechów należy uwzględnić następujące parametry:

- odległość siodeł naczepy od siodeł adapterów przed osadzeniem naczepy na adapterach $150 \mathrm{~mm}$,

- ugięcie usprężynowania wózków po osadzeniu naczepy na adapterach $-40 \mathrm{~mm}$,

- odprężenie opony po uniesieniu osi drogowych - $40 \mathrm{~mm}$,

- ugięcie ramy naczepy od ciężaru ładunku - 35 $\mathrm{mm}$,

- zużycie obręczy kół zestawów kołowych wózków $-30 \mathrm{~mm}$.

Suma wartości wyżej wymienionych parametrów wynosi $295 \mathrm{~mm}$. Skok miechów nośnych powinien być zatem większy niż $295 \mathrm{~mm}$. Uwzględniając - $45 \mathrm{~mm}$ rezerwy, należy założyć ze skok miechów o wartości $340 \mathrm{~mm}$ jest wystarczający do oderwania się opon od powierzchni oparcia na środkowym segmencie stanowiska oraz zachowania skrajni taboru w dolnej części zarysu skrajni kolejowej.

Przedstawiony $\mathrm{w}$ omawianej koncepcji sposób rozwiązania łączenia naczepy $\mathrm{z}$ adapterami pozwala również wykorzystać typową metodę przeładunku pionowego naczepy za pomoca powszechnie stosowanych urządzeń dźwigowych (1) wyposażonych w chwytaki kleszczowe (2) (rys. 12a). Metodę załadunku naczepy pokazano schematycznie na rysunkach 12 i 12a. W tym rozwiązaniu połączono adaptery sąsiednich wózków belką dystansową (3), której zadaniem jest utrzymanie stałej odległości pomiędzy wózkami, zagwarantowanej konstrukcyjnie, podczas załadunku naczep na adaptery.
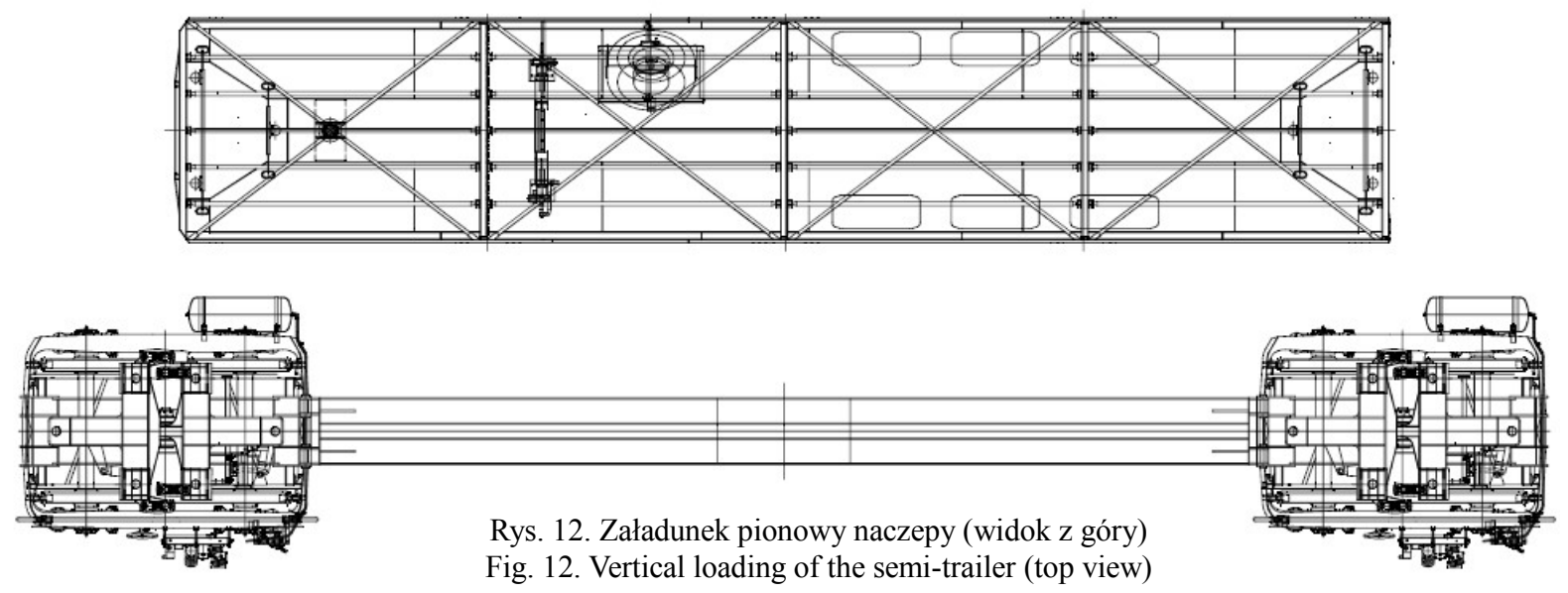


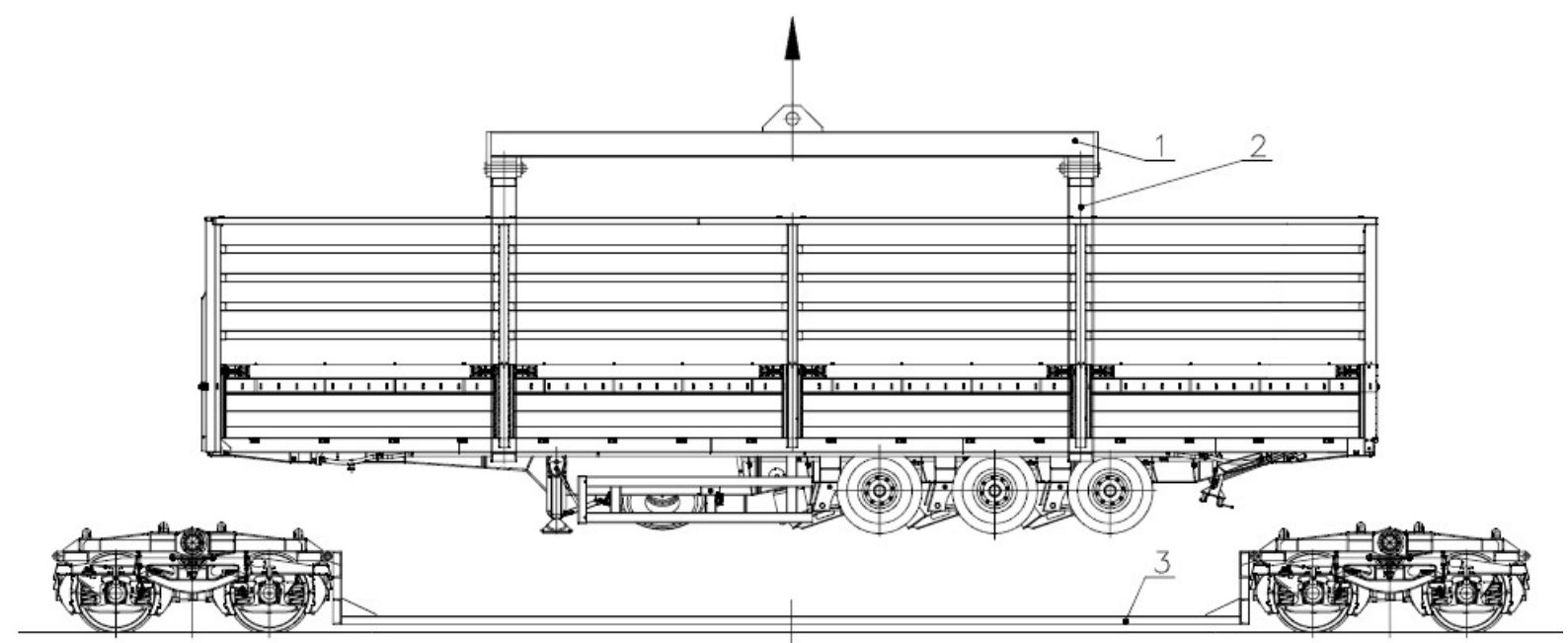

Rys. 12a. Załadunek pionowy naczepy (widok boczny)

Fig. 12a. Vertical loading of the semi-trailer (side view)

- decompressing of the tire after lifting of the road axles $-40 \mathrm{~mm}$,

- deflection of the semi-trailer's frame from the weight of load $-35 \mathrm{~mm}$,

- wear of the wheels' rim of the bogies - 30 $\mathrm{mm}$.

The sum of the values of the above mentioned parameters is $295 \mathrm{~mm}$. Therefore, the stroke of the bellows should be larger than $295 \mathrm{~mm}$. Taking into account $-45 \mathrm{~mm}$ reserve, it should be assumed that the stroke of bellows of $340 \mathrm{~mm}$ is enough for taking the tires off the surface of the support on the central segment of the stand and keeing the gauge of the rolling stock at the bottom part of the outline of railway gauge.

The solution of connecting of the semi-trailer with adapters, presented in the discussed conception, also allows to use the typical method of vertical transhipment of the semi-trailer by means of the commonly used lifting devices (1) equipped with grippers (2) (Fig. 12a). The loading method of the semi-trailer is shown schematically in Figures 12 and 12a. In this solution, the adapters of neighboring bogies are joined with a distance beam (3), whose task is to maintain a constant distance between the bogies, guaranteed constructionally, during the loading of the semi-trailers on the adapters.

\section{Possibilities of operation activities automation}

In order to limit the manual operation activities during transhipment of semi-trailer, it should be considered the automation of the individual stages of loading of the semi-trailer on the bogies' adapters:

- displacement of the semi-trailer to the longitudinal axis of the track,

- lowering of the semi-trailer's body to the support on the adapters,

- locking of the semi-trailer on the adapters,

- locking of the road axles after their lifting.

\section{Możliwości automatyzacji czynności obsługo-} wych

W celu ograniczenia ręcznych czynności obsługowych przy przeładunku naczepy należy rozważyć automatyzację poszczególnych etapów załadunku naczepy na adaptery wózków:

- przemieszczenie naczepy do osi wzdłużnej toru,

- opuszczenie nadwozia naczepy do oparcia na adapterach,

- zaryglowanie naczepy na adapterach,

- zaryglowanie osi drogowych po ich uniesieniu.

Automatyzację procesów przeładowania naczepy należy poprzedzić analizą ekonomiczną opłacalności przedsięwzięcia w której powinno się uwzględnić następujące elementy:

- koszt budowy stanowisk przestawczych z ręcznym sterowaniem przeładunku,

- koszt automatyzacji wszystkich lub wybranych etapów przeładunku,

- liczba osób obsługi procesu przeładunku, przed i po procesie automatyzacji,

- czas przeładunku naczepy bez i z procesem automatyzacji.

Ekonomiczny efekt końcowy - porównanie kosztów przeładunku ze sterowaniem ręcznym i automatycznym - winien stanowić podstawę do podjęcia decyzji o częściowej lub kompleksowej automatyzacji procesu przeładunku naczep.

\section{Podsumowanie}

Przedstawiona w niniejszej publikacji koncepcja poziomego, poprzecznego przeładunku naczep bimodalnych pozwala na skrócenie czasu formowania i rozformowywania pociagu bimodalnego $\mathrm{w}$ odniesieniu do systemu TABOR 1 i TABOR 2 opracowanych w przeszłości w Instytucie Pojazdów Szynowych „TABOR”. W opracowanych w IPS „TABOR” systemach transportu bimodalnego wykorzystano koncepcje szeregowego załadunku naczep bimodalnych na wózki kolejowe. Formowanie składu pociagu w tym przypadku jest 
Automation of semi- trailer transhipment processes should be carried out with an economic analysis of the undertaking profitability, in which the following elements should be considered:

- building cost of the change-over stands with manual transhipment control,

- automation cost of all or selected transhipment stages,

- number of persons of transhipment process operation, before and after the automation process,

- transhipment time of the semi-trailer, without and with the automation process.

Economic final result - comparison of transhipment costs with manual and automatic control - should be the basis for making a decision about partial or comprehensive automation of the semi-trailer transhipment process.

\section{Summary}

The concept of horizontal, transverse transshipment of bimodal semi-trailers presented in this publication allows for shortening the time of coupling and uncoupling of the bimodal train with reference to the TABOR 1 and TABOR 2 systems developed in the past at the Rail Vehicles Institute „TABOR”.

The conceptions of serial loading of bimodal semitrailers on the railway bogies are used in the bimodal transport systems developed in the IPS "TABOR". Forming of the train set in this case is timeconsuming, but does not require using of the auxiliary equipment to form the set of the bimodal train.

The presented method of transhipment of the semitrailers in a parallel loading system allows for a decisive reduction of train set formation time by equipping the terminal with the appropriate transhipment stands, which theoretically enable the simultaneous loading of semi-trailers onto the railway bogies. The proposed method of transshipment of semi-trailers allows to automate the transhipment process of semitrailers completely or partially. czasochłonne lecz nie wymaga stosowania urządzeń pomocniczych do sformowania składu pociagu bimodalnego.

Prezentowana metoda przeładunku naczep w systemie załadunku równoległego pozwala na zdecydowane skrócenie czasu formowania składu pociagu przez wyposażenie terminala $\mathrm{w}$ odpowiednie stanowiska przeładunkowe, które teoretycznie umożliwiają równoczesny załadunek naczep na wózki kolejowe. Proponowana metoda przeładunku naczep pozwala na zautomatyzowanie całkowite lub częściowe procesu przeładunku naczep.

\section{Bibliography / Bibliografia}

[1] Medwid M. , Cichy R.: Techniczne Środki Transportu Kombinowanego Kolejowo-Drogowego. Instytut Pojazdów Szynowych „,TABOR”., Poznań 2017.

[2] Medwid M.: Polski system transportu kolejowodrogowego (bimodalnego) typu TABOR. Instytut Pojazdów Szynowych ,TABOR”., Poznań 2006.

[3] Madej J.: Techniczno-gospodarcze korzyści zastosowania techniki bimodalnej. Materialy sympozjum „,Transport kombinowany”, Zakopane 1997.

[4] Madej J.: Zasady weryfikacji modeli pociagu bimodalnego $w$ zakresie quasistatyki i dynamiki. Zeszyty Instytutu Pojazdów Politechniki Warszawskiej nr 5, 1999.

[5] Medwid M., Cichy R., Przepióra K.: Geometryczna analiza mega naczepy bimodalnej na wózkach bezadapterowych. Materiaty XVII konferencji naukowej „Pojazdy szynowe”, Kazimierz Dolny 2006.

[6] Medwid M., Phol K.: Dwudzielny adapter dla transportu drogowo-szynowego. Materiaty z sympozjum monotematycznego „Techniczne środki transportu drogowo-szynowego", Poznań-Skoki 1993.

[7] Medwid M., Phol K.: Uwarunkowania rozwoju nowych systemów transportu kombinowanego, zwłaszcza bimodalnego. Materialy I konferencji „,Transport multimodalny", Jastrzębia Góra 1998.

[8] Medwid M., Przepióra K.: Wykorzystanie techniki bimodalnej do transportu kontenerów i pojemników wymiennych. Pojazdy Szynowe nr 2, 2005.

[9] Medwid M.: Atrybuty polskiej myśli technicznej w taborze bimodalnym. Materiaty konferencji naukowej „,Wybrane problemy transportu szynowego w 150-lecie Kolei Polskich", Kraków-Zakopane 1997. 